\title{
Access to Sharia Financing for Micro Enterprises: Case Study of Micro Enterprises in Semarang, Indonesia
}

\author{
Mutoharoh $^{1}$ \\ Fakultas Ekonomi \\ Universitas Islam Sultan Agung, \\ Indonesia
}

\author{
Kiryanto ${ }^{2}$ \\ Fakultas Ekonomi \\ Universitas Islam Sultan Agung, \\ Indonesia
}

\begin{abstract}
Surel : mutoharoh@unissula.ac.id
ABSTRACT

Islamic banking by its principle is expected to play a dominant role compared to other funding providers to finance micro enterprises, which are the real industrial sector. This study aims to explain the perceptions of micro business actors based on their experience in accessing Islamic financing. This is a descriptive quantitative research that relies on the sample selected using purposive random sampling to obtain respondents who meet the criteria that support the research objectives. Primary data were collected through a structured questionnaire to owners and managers of micro-businesses in the Semarang and surrounding areas. A total of 184 data were obtained and processed with the help of statistical tools that is SPSS 22.0. Therefore, it is concluded that access to Islamic financing in terms of product, requirements, and services variables was quite good based on micro business actors' view.
\end{abstract}

Keywords: Access of Financing; Micro Enterprises; Islamic Bank.

\section{Akses Pembiayaan Syariah bagi Usaha Mikro: Studi Kasus Pengusaha Mikro di Semarang}

\begin{abstract}
ABSTRAK
Perbankan syariah dengan prinsipnya diharapkan memainkan peran yang dominan dibandingkan dengan Lembaga penyedia dana yang lain dalam hal permodalan bagi usaha mikro yang merupakan sektor industri riil. Penelitian ini bertujuan untuk menjelaskan persepsi pelaku usaha mikro berdasarkan pengalaman mereka dalam akses pembiayaan Syariah. Jenis penelitian ini adalah kuantitatif deskriptif dengan sampel penelitian dipilih secara purposive random sampling untuk mendapatkan responden yang memenuhi kriteria yang mendukung tujuan penelitian. Data primer dikumpulkan melalui kuesioner terstruktur terhadap pemiliki maupun pengelola usaha mikro di wilayah Semarang dan sekitarnya. Sebanyak 184 data diperoleh dan diolah dengan bantuan alat statistic SPSS 22.0. Dengan demikian disimpulkan bahwa akses pembiayaan Syariah berdasarkan variabel produk, persyaratan, dan pelayananannya secara cukup baik dirasakan oleh para pelaku usaha mikro.
\end{abstract}

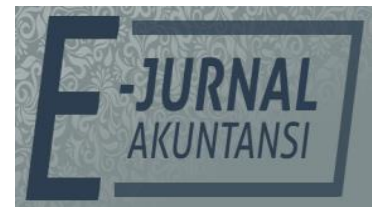

e-ISSN 2302-8556

Vol. 31 No. 5

Denpasar, Mei 2021

Hal. 1247-1262

DOI:

10.24843/EJA.2021.v31.i05.p13

PENGUTIPAN:

Mutoharoh \& Kiryanto.

(2021). Access to Sharia

Financing for Micro Enterprises: Case Study of

Micro Enterprises in

Semarang, Indonesia. EJurnal Akuntansi, 31(5), 1247-

1262

RIWAYAT ARTIKEL:

Artikel Masuk:

18 Januari 2021

Artikel Diterima:

24 Mei 2021

Kata Kunci: $\quad$ Akses Pembiayaan; Usaha Mikro; Bank Syariah.

Artikel dapat diakses : https://ojs.unud.ac.id/index.php/Akuntansi/index 


\section{INTRODUCTION}

Banks or other legal lending institutions apply strict procedures in facilitating micro and small credit (Shaban, Duygun \& Fry, 2016). This happens because banks or creditors are avoiding facing high risks in accepting not eligible customers (Nightingale \& Coad, 2014), (Lee, Sameen \& Cowling, 2015), (Wardani \& Pramono, 2016), and (Prijadi et al., 2020). Compared to conventional banks, the treatment of sharia banks to its customers is considered fairer because the implementation of service aspects for the welfare of the ummah is one of the objectives in sharia-based services (Yussuf, 2017). Thus, there is no discrimination in services that can violate the principles of sharia law (Shaban, Duygun and Fry, 2016). With regards to its type of transaction, customers have alternative financing contracts that can be selected according to their ability to fulfill repayments. Yussuf, (2017) mentions that the unique features of Islamic financing are solutions in order to encourage economic growth. Various financing schemes (Hadzic and Pavlovic, 2019), (Ali, Ahmad \& Kamaruddin, 2020), (Ali, Bushera \& Yesuf, 2020), dan (Nugroho \& Nugraha, 2020) support business development. In the case of sharia financing, the available schemes provide high flexibility for both parties (customers and banks) by integrating assets and debts belonging to both customers and banks related to the business.

However, Huda, (2012) concluded that Islamic banks impose higher margins than conventional banks in their financing contracts. The problem of bad loans faced by Islamic banks is also higher than conventional banks (Huda, 2012; Nightingale and Coad, 2014). This is very possible resulted by the information asymmetry factor (O'Sullivan, 2005) and (Lee, Sameen \& Cowling, 2015) where entrepreneurs know better about the risks of the business or project they are working on. When they find out that their project is a high risk, they will take advantage of the loan in an effort to ensure the potential losses they will face. Previous research has discussed various challenges and factors that hinder the performance of micro-businesses (Shaban, Duygun \& Fry, 2016) and (Wardani \& Pramono, 2016). This study provides a more specific review on the perspective of micro entrepreneurs regarding access to Islamic finance. The purpose of this research is to analyze how the accessibility of micro enterprises in Semarang city and its surroundings in obtaining Islamic financing. Theoretically, the results of this study are expected to enrich the literature and become a reference in the field of accounting, especially those related to the sustainability of micro-business businesses. While practically this research is expected to provide knowledge to micro business actors regarding the use of Islamic financing in terms of ease of access. Moreover, this research is also expected to be used as an evaluation material for the Sharia financing service policy for related parties.

The number of micro businesses registered in the Semarang Cooperatives and MSMEs Office Data as of December 2020 is 16,484 units. This number dominates the MSMEs classification in Semarang compared to 1,097 small-scale businesses and 21 medium-sized businesses. A survey by Margunani, Setiawan \& Kistant (2019) explains that most of the business actors depend on financial institutions to fulfill their capital needs. The problem is, their accessibility to bank financing, including Islamic banking, is quite low. As a result, more business actors use informal financial institutions as a source of financing (Margunani, 
Setiawan \& Kistant, 2019). Most of the micro businesses in Semarang are homebased businesses using very limited personal production and sales instruments. They use relatively low venture capital to start a business. However, as their businesses run, many of them are failed and close due to insufficient capital. The main problem related to this is that although micro businesses are feasible in terms of business types, most of them do not meet the bankable criteria. Various factors result in credit accessibility problems for micro entrepreneurs.

The problem in access to finance sometimes does not really arise because of the criteria for a non-bankable business. Wasiuzzaman et al. (2020) argue that the interest factor usually set by banks makes entrepreneurs reluctant to take advantage of financing. As stated in the pecking order theory, even though companies are able to generate decent profits and have access, they prefer to use retained earnings or internal funds instead of utilizing external sources of capital as it is more expensive. The elimination of interest, which was replaced by a profit-sharing scheme, has become a bridge for the capital needs of microbusinesses and access to Islamic financing (Nugroho \& Nugraha, 2020). Profit sharing schemes offer a more efficient and optimal allocation of resources than the interest system (Ellahi, Bukhari \& Naeem, 2010). Interest-free financial services are in great demand for business actors, both Muslim and non-Muslim. Islamic banking also provides various financing schemes in accordance with Sharia principles. Ali, Ahmad \& Kamaruddin (2020) stated that the variation of Islamic bank financing schemes is an instrument that can be adjusted for business improvement and the socio-economic balance of poor business actors. The various Sharia financing schemes also offer wider opportunities for more real customer needs. In addition, spiritual commitment for both parties can increase security and comfort in the issue of access to Islamic finance. Asset integration (Elasrag, 2016) and (Thaker, Kanan \& Sakaran, 2019) between fund providers and fund users and the aspect of honesty becomes the basis for transactions in Islamic financing. Based on the framework above, the first hypothesis (H1) is taken that access to Islamic finance is quite good in terms of financing products based on the interest system, implementation of profit sharing, diversity of choice, and security.

The simple procedure creates greater opportunities for microbusinesses (Yussuf, 2017). Business actors expect simple financing products and procedures so that they understand the financing rules they take and are able to meet all requirements. Ease of transactions is part of Sharia banking services (Biancone \& Radwan, 2015) and be a form of social responsibility for Islamic banking to attract public trust that they implement the essential objectives of sharia for the welfare of the ummah. Nurhasanah, Nurhayati \& Surahman (2020) also found that in terms of access to finance, one of the challenges faced by microfinance is related to high administrative costs. Micro businesses with very limited assets and turnover are carried out by people with the low social and economic class. Micro-business actors are still quite hard in obtaining income stability that can secure their business profits and meet administrative requirements in financing. Thus, Sharia financing services are expected to offer sufficiently mitigating administrative procedures for micro businesses, including those related to the establishment of affordable administrative costs and collateral. The 
creditworthiness assessment at commercial banks adopts the 5 Cs criteria, namely character, capacity, capital, condition, and collateral. For micro businesses, this assessment is very strict because micro-businesses are seen as customers with high potential risks (Ali, Bushera \& Yesuf, 2020) dan (Wasiuzzaman et al., 2020). This standard may be applied by conventional banks as an effort to hedge against risk if the borrower experiences default (Yussuf, 2017). As the establishment of micro-businesses is very limited, it is difficult to fulfill the collateral requirements for access to credit. Moreover, the problem raised related to the long waiting time because legal fund providers need to ensure that customers meet creditworthiness. It is hoped that the quality of financial services provided to micro businesses will reduce transaction costs and waiting times (Wasiuzzaman et al., 2020). Therefore, it is concluded in the second hypothesis (H2) that access to Islamic finance is quite good in terms of financing procedures based on convenience, affordability, collateral flexibility, and duration.

The accessibility problems faced by micro businesses are also caused by the lack of awareness of entrepreneurs about the loan facilities provided by banks and government institutions (Thaker, Kanan \& Sakaran, 2019). Technological advances and innovations have however influenced the banking industry. However, even though technological sophistication has become a necessity for the community, it is undeniable that micro-entrepreneurs, especially those from rural areas, have not been reached by digital-based information. Therefore, information dissemination is still needed through various media, both print and digital media. Nugroho \& Nugraha (2020) said that the need to access information has an impact on changing people's behavior to meet the needs of business and financial transactions. In this case, the behavior of micro entrepreneurs in making financing decisions will also be influenced by the information they found. Regarding the financing facilities provided by Islamic banking, the function of the bank is expected not only as a party to obtain funding, but also to provide financial consultation services to micro entrepreneurs so that they can manage their finance appropriately (Nugroho \& Nugraha, 2020). Consulting facilitation can be provided through explanations that are easily accepted by customers from friendly employees who are familiar with Sharia financing products. Ali, Bushera \& Yesuf (2020) explain that the potential and ability of Islamic banks in distributing their products for the benefit of the ummah are still experiencing obstacles. This is partly due to the inadequate support environment and the lack of a competent workforce in mastering knowledge of Sharia concepts. Therefore, this study takes three main problems to be analyzed which include financing products, procedures, and services. Related to service variables, the third hypothesis $(\mathrm{H} 3)$ is determined that access to Islamic finance is quite good in terms of financing services based on consulting services, availability of information, friendly and insightful officer. 


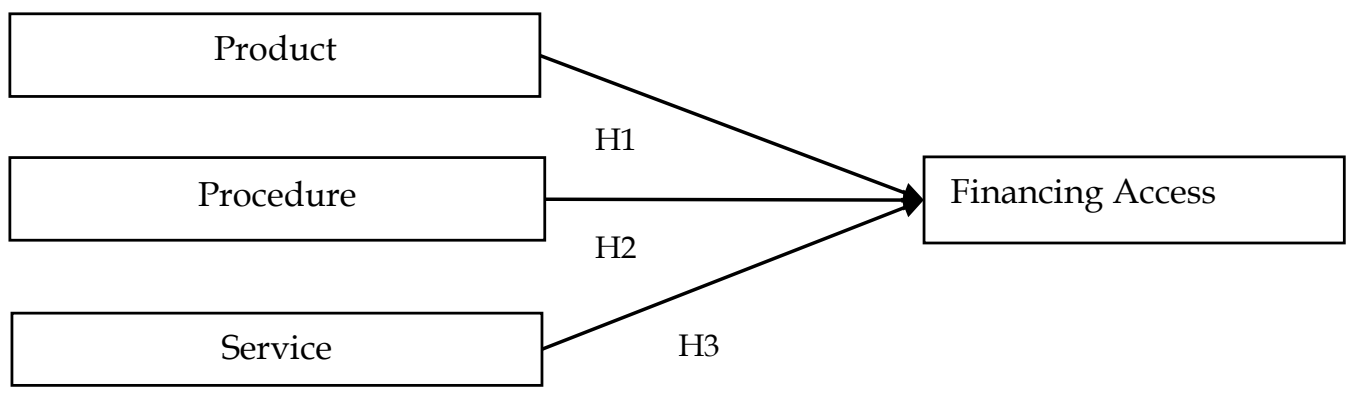

Figure 1. Conceptual Framework

Source: Research Data, 2020

\section{RESEARCH METHOD}

This study uses a descriptive quantitative approach to answer research questions. Primary data were collected through questionnaire distribution to respondents and then developed with a literature review. Questions raised regarding the experience of micro enterprise actors in accessing Islamic financing are converted into a Linkert scale. Questions are divided into several sections. the first part contains general questions about the respondent's personal and business identity. The second part contains questions related to the research variables which are product, procedures, and services.

The test seeks the mean, frequencies, and percentages from the data analysis for each variable. Results of the study were presented in tables and bar graphs. In data processing, researchers used SPSS tools with the analysis techniques of descriptive statistical tests. The test is used to measure respondents' answers to the following indicators.

Table 1. Research Variables and Indicators

\begin{tabular}{|c|c|c|}
\hline No. & Variables & Indicators \\
\hline 1. & Product & $\begin{array}{l}\text { - Interest free (Nugroho and Nugraha, 2020) } \\
\text { - The implementation of profit-loss sharing (Ali et al., 2020; } \\
\text { Ellahi et al., 2010; Nugroho \& Nugraha, 2020) } \\
\text { - Various product scheme (Ali, Ahmad, \& Kamaruddin, } \\
2020 \text {;Ellahi et al., 2010) } \\
\text { - The Financing contract security (Elasrag, 2016; Thaker, } \\
\text { Kanan and Sakaran, 2019) }\end{array}$ \\
\hline 2. & Procedure & $\begin{array}{l}\text { - The easiness of procedure (Huda, 2012; Yussuf, 2017) } \\
\text { - The affordability of installment (Nurhasanah, Nurhayati } \\
\text { and Surahman, 2020) } \\
\text { - The flexibility of collateral (Elasrag, 2016; Yussuf, 2017; } \\
\text { Thaker, Kanan and Sakaran, 2019) } \\
\text { - The duration of the financing submission procedure } \\
\text { (Wasiuzzaman et al., 2020) }\end{array}$ \\
\hline 3. & Service & $\begin{array}{l}\text { - Consultation service (Thaker, Kanan and Sakaran, 2019) } \\
\text { - The availability of information (Nugroho and Nugraha, } \\
\text { 2020) } \\
\text { - Friendly officer (Ali, Bushera and Yesuf, 2020) } \\
\text { - Insightful officer (Ali, Bushera and Yesuf, 2020) }\end{array}$ \\
\hline
\end{tabular}

Source: Research Data, 2020 
The population of this research is a micro business that operates in Semarang and its surroundings. Based on the data from The Cooperative and MSMEs Office of Semarang as of December 2020 the total of micro enterprises in Semarang was 16,484 units. The samples were selected using purposive random sampling method with the criteria that the micro enterprises have experience in utilizing Sharia financing. The population and sampling technique were selected by adjusting the flexibility of the researcher in obtaining information from respondents. A total of 300 questionnaires were distributed and 271 of them returned to the researchers. However, based on the validation process, only 184 data that fit the research criteria with complete answers and able to be processed.

\section{FINDINGS AND DISCUSSION}

In filling out the questionnaire, respondents are asked to choose the type of micro business that is in accordance with the one being run. The options provided consist of manufacturing, trading and service businesses. It was found that as many as 121 (66 percent) of respondents ran a manufacturing business. This amount is the largest number compared to other types of businesses. As many as 34 (18 percent) of respondents run trading businesses and 29 (16 percent) of respondents run service businesses. From the respondent's information, the types of products and services offered are very diverse. The types of products provided are processed food products, clothing and handicrafts, while the types of services offered are tailors, workshops, salons and printing services. These results indicate that the distribution of the questionnaire includes respondents from various types of micro enterprises in general.

Moreover, respondents were also asked to fill in the length of the period the business has been running based on the options provided. In the questionnaire, the business period is divided into 5 categories, namely 1 year, 2 years, 3 years, 4 years, and more than equal to 5 years.

\section{Respondents' Enterprise Ages}

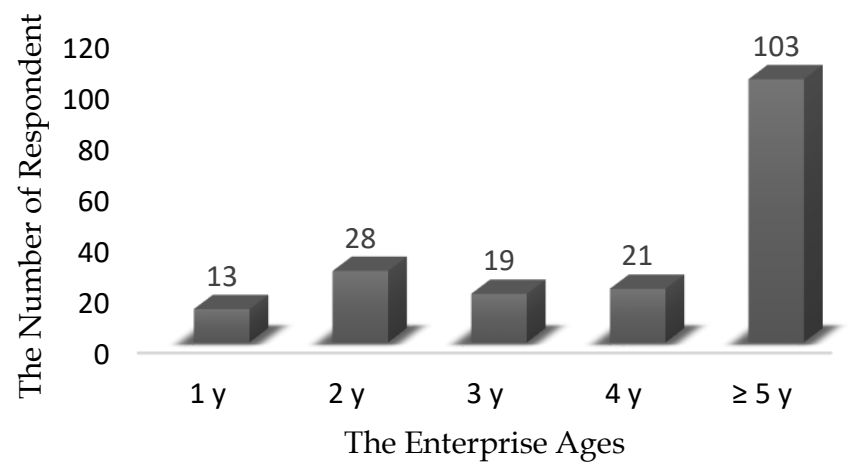

Figure 2. Respondents' Enterprise Ages

Source: Research Data, 2020

The results show that the majority of respondents have been running their business for a long period of time, namely more than equal to five years. As much as more than half of the respondents (56 percent) answered that their business was more than 5 years old. The smallest number of respondents 
answered that they have been operating for 1 year as much as 7.1 percent. This number is not much different from the answers to other choices, which are 10.3 percent for 3 years of business age, 11.4 percent for 4 years of business age, and 15.2 percent for 2 years of business age. The age of the business shows that a business actor has sufficiently mature experience to operate his business. This answer shows a fairly long period that has been passed by micro entrepreneurs. However, they have not experienced significant development, as evidenced by the majority of business answers for more than 5 years and they are still in the micro business scope.

The results of descriptive statistical testing for each research variable consist of frequency, percentage, mean and standard deviation. Respondents' experience in access to Islamic financing is analyzed based on the answers to the questionnaires. The answer is translated using a Likert scale with a range of 1-5 which includes 1 = very bad, 2 = bad, 3 = fairly enough, 4 = good, 5 very good.

Sharia financing products, as in principle, must be free of usury (riba), so Islamic banking applies an interest-free financing system. The following are the perceptions of the respondents regarding their experiences in obtaining the opportunity to take advantage of interest-free financing.

Table 2. Descriptive Statistical Results of Product on Interest-free System

\begin{tabular}{llll}
\hline & Frequency & Valid Percent \\
\hline Valid & 1 & 2 & 1,1 \\
& 2 & 7 & 3,8 \\
& 3 & 46 & 25,0 \\
& 4 & 94 & 51,1 \\
Total & 5 & 35 & 19,0 \\
Mean & & 184 & 100,0
\end{tabular}

Source: Research Data, 2020

The test results show that the opportunity for micro businesses to obtain interest-free financing is at an average value of 3,83, which is close to the "good" answer on a scale of 4 . Most answers of 51 percent answered "good" while 25 percent of respondents thought "enough". Fewer than 10 people expressed disagreement with the opportunities available to obtain interest-free financing for microbusinesses and 35 responded consider it a very well experience in terms of the opportunities they get in taking advantages of interest-free financing.

Table 3. Descriptive Statistical Results of Product on Implementation of profitsharing scheme

\begin{tabular}{llll}
\hline & Frequency & Valid Percent \\
\hline Valid & 1 & 3 & 1.6 \\
& 2 & 6 & 3.3 \\
& 3 & 55 & 29,9 \\
& 4 & 100 & 54,3 \\
Total & 5 & 20 & 10,9 \\
Mean & & 184 & 100,0 \\
\hline
\end{tabular}

Source: Research Data, 2020 
The research data above shows that as many as 100 people stated that the implementation of the profit-sharing scheme in Islamic financing was good. Nearly 30 percent of respondents expressed a sufficient opinion, while 3,3 percent and 1,6 percent others answered bad and so bad. More than 10 percent of respondents indicated their satisfaction with the profit-sharing scheme they utilized by stating "very good" answers.

Various financing models are provided by Islamic banking to achieve the sharia objective in the ummah welfare. This includes the provision of schemes that are most suitable for the needs of micro-entrepreneurs. The perceptions of micro business actors based on their experience with the variety of sharia financing products are presented in the table 4.

Table 4. Descriptive Statistical Results of Product on Variations

\begin{tabular}{llll}
\hline & Frequency & Valid Percent \\
\hline Valid & 1 & 2 & 1,1 \\
& 2 & 9 & 4,9 \\
& 3 & 74 & 40,2 \\
& 4 & 82 & 44,6 \\
Total & 5 & 17 & 9,2 \\
Mean & & 184 & 100,0 \\
\hline
\end{tabular}

Source: Research Data, 2020

A quite small difference is found in the answer of "adequate" and "good". There were 6 people more who answer on a scale of 4 with resulting the percentage of 44,6 percent. Only 2 respondents thought that the variation of Sharia financing from their experiences was "very bad" and 9 people thought "bad". However, 17 people stated that the variety of Sharia financing products was very good.

The financing amount for each micro business is quite small when compared to businesses with a larger level. However, the protection of assets both for customers and fund providers must be keep guaranteed. The following table shows the respondents' perceptions of the security they feel in accessing Sharia financing.

Table 5. Descriptive Statistical Results of Product on Security

\begin{tabular}{llll}
\hline & Frequency & Valid Percent \\
\hline Valid & 1 & 0 & 0,0 \\
& 2 & 10 & 5,4 \\
& 3 & 42 & 22,8 \\
& 4 & 94 & 51,1 \\
Total & 5 & 38 & 20,7 \\
Mean & & 184 & 100,0
\end{tabular}

Source: Research Data, 2020

More than 50 percent of respondents feel safe in accessing Sharia financing and another 20.7 percent stated that they are very safe according to their answers on a scale of 4 and 5. These answers affect the average value of the sense of security in access to Sharia financing by 3,87, which is close to the 
"good" category. No one thought it was very bad, but 10 people thought that the security of access to Islamic finance is just bad.

Respondents' statements were also analysed in terms of fulfilling the requirements in Sharia financing, including their ability to pay off both principal installment and the agreed profit-sharing margin. The data shows that 50.5 percent stated that the ease of fulfilling their installment obligations was "good" and 37 percent of respondents answered "enough. Only 4,3 percent of respondents answered below a scale of 3 and 8,2 percent of respondents answered on a scale of 5 .

Table 6. Descriptive Statistical Results of Procedure on the Easiness

\begin{tabular}{llll}
\hline & & Frequency & Valid Percent \\
\hline Valid & 1 & 0 & 0.0 \\
& 2 & 8 & 4.3 \\
& 3 & 68 & 37.0 \\
& 4 & 93 & 50.5 \\
Total & 5 & 15 & 8.2 \\
Mean & & 184 & 100.0 \\
\hline
\end{tabular}

Source: Research Data, 2020

In applying for financing, micro entrepreneurs still have to meet several requirements. Hence, the test results show that the average value given by the respondents is 3,59 which means good enough. There are 69 people who find it fairly easy and 91 people find it easy to fulfill the requirements in applying for Sharia financing. Only 1 person said it was very difficult while 14 others said it was very easy.

Table 7. Descriptive Statistical Results of Procedure on the Affordability

\begin{tabular}{llll}
\hline & Frequency & Valid Percent \\
\hline Valid & 1 & 1 & .5 \\
& 2 & 9 & 4.9 \\
& 3 & 69 & 37.5 \\
& 4 & 91 & 49.5 \\
Total & 5 & 14 & 7.6 \\
Mean & & 184 & 100.0
\end{tabular}

Source: Research Data, 2020

Respondents were asked to state their experience related to the obligation to provide asset collateral in proposing financing. Unlike some of the previous statistical results where there were more answers on scale 4 than on scale 3 , in this statement more respondents said that it was enough. More than 20 people declared it bad and very bad. Even less than 5 percent of respondents answered very well regarding their ability to fulfill the guarantee obligation under the Sharia financing scheme.

The simple procedure requires a short duration. In this case, respondents were asked to state their experience related to the time they have to spend to carry out the financing application procedure. Only 5.4 percent of respondents answered "very good", which means that the duration they feel is very short based on their perception. Respondents who thought "good" were 80 people and 
"enough" were 73 people with a total percentage of both 83,2 percent. an average value of 3,42 means that the respondent needs a fairly short duration in the procedure for applying for Islamic financing to obtain the disbursement of funds they need.

Table 8. Descriptive Statistical Results of Procedure on Collateral Flexibility

\begin{tabular}{llll}
\hline & & Frequency & Valid Percent \\
\hline Valid & 1 & 2 & 1.1 \\
& 2 & 19 & 10.3 \\
& 3 & 80 & 43.5 \\
& 4 & 75 & 40.8 \\
Total & 5 & 8 & 4.3 \\
Mean & & 184 & 100.0
\end{tabular}

Source: Research Data, 2020

Regarding the facilitation of consultations on products in Islamic financing, the respondent's data resulted in an average score of 3,73 , which is close to a "good" score. There is still 1 respondent who thinks this facilitation is very bad. However, more than 30 people have the opposite opinion, that the facilitation of Sharia financing product consultations is very good. In addition, 32.6 percent of respondents answered "enough" and 43,5 percent of respondents answered "good".

Table 9. Descriptive Statistical Results of Procedure on Process Duration

\begin{tabular}{llll}
\hline & Frequency & Valid Percent \\
\hline Valid & 1 & 2 & 1.1 \\
& 2 & 19 & 10.3 \\
& 3 & 73 & 39.7 \\
& 4 & 80 & 43.5 \\
Total & 5 & 10 & 5.4 \\
Mean & & 184 & 100.0 \\
\hline
\end{tabular}

Source: Research Data, 2020

The results above indicate that Islamic banking has fulfillled customer satisfaction with the facilitation of consultation regarding Islamic financing products is almost satisfactorily.

Table 10. Descriptive Statistical Results of Service on Consultation Facility

\begin{tabular}{llll}
\hline & & Frequency & Valid Percent \\
\hline Valid & 1 & 1 & .5 \\
& 2 & 10 & 5.4 \\
& 3 & 60 & 32.6 \\
& 4 & 80 & 43.5 \\
Total & 5 & 33 & 17.9 \\
Mean & & 184 & 100.0
\end{tabular}

Source: Research Data, 2020

Financing customers need to understand products that suit their needs and abilities. By obtaining information from various media, both available in printed versions, such as brochures and digital information, will help micro entrepreneurs understand the Sharia financing scheme. 
Therefore, customers are asked to state their opinion regarding the availability of information about Sharia financing products that will help them finally choose a particular product. The test results proved that the available information was quite good, as evidenced by 33,2 percent of customers saying it was "sufficient" and 45,7 percent saying it was good. In addition, 12,5 percent answered that the availability of the information was very good, while the remaining 7,6 percent and 1,1 percent answered bad and very bad.

Table 11. Descriptive Statistical Results of Service on Information Avilability

\begin{tabular}{llll}
\hline & & Frequency & Valid Percent \\
\hline Valid & 1 & 2 & 1,1 \\
& 2 & 14 & 7,6 \\
& 3 & 61 & 33,2 \\
& 4 & 84 & 45,7 \\
Total & 5 & 23 & 12,5 \\
Mean & & 184 & 100,0 \\
\hline
\end{tabular}

Source: Research Data, 2020

Customers interact directly with Islamic bank employees in every transaction related to Sharia financing, whether in their submission, disbursement, to repayment.

Table 12. Descriptive Statistical Results of Service on Friendly Officer

\begin{tabular}{llll}
\hline & Frequency & Valid Percent \\
\hline Valid & 1 & 2 & 1,1 \\
& 2 & 11 & 6,0 \\
& 3 & 48 & 26,1 \\
& 4 & 94 & 51,1 \\
Total & 5 & 29 & 15,8 \\
Mean & & 184 & 100,0 \\
\hline
\end{tabular}

Source: Research Data, 2020

Based on the respondents' experiences, they found that employees were quite good at providing services related to their friendliness and behavior. More than 50 percent of respondents agree that Islamic banking employees are well behaved and 15,8 percent of respondents have very good experiences in interacting. The average score in this case shows a score of 3,74, which means that most of the Sharia financing customers state that they are served quite friendly and politely in their financing transactions.

Half of the respondents stated that they met employees who were good masters of the Sharia financing products they needed. This is very helpful for customers to obtain information that is easily accepted and not misleading.

It is also found from the test results that there is a very bad experience as much as 1,1 percent in terms of mastery of employee information according to the respondent's opinion. However, the average value of employees who mastered information was still quite good at a score of 3,83 . The results above indicate that more of the respondents are satisfied with the information conveyed 
by bank employees in Islamic financing services because they master the information quite well.

Table 13. Descriptive Statistical Results of Service on Insightful Officer

\begin{tabular}{llll}
\hline & & Frequency & Valid Percent \\
\hline Valid & 1 & 2 & 1,1 \\
& 2 & 8 & 4,3 \\
& 3 & 46 & 25,0 \\
& 4 & 92 & 50,0 \\
Total & 5 & 36 & 19,6 \\
Mean & & 184 & 100,0 \\
\hline
\end{tabular}

Source: Research Data, 2020

The findings in access to Islamic financing for micro businesses related to the micro business product factor prove that customers are quite satisfied. The majority of respondents have provided sufficient, good and very good answers to Islamic financing products based on their experience. Sharia principles in financing are implemented, one of which is related to the product with an interest-free scheme. In general, the interest scheme for customers is seen as burdensome. In fact, not a few customers experience defaults in fulfilling interest expense installments. In conventional theory, the creditor has the right to collect interest from the debtor in any condition, whether the businesses in a profit or a loss condition. Interest is agreed at the beginning of the contract with certain payments and a fixed value. For micro businesses with limited availability of funds and high uncertainty over their income, the interest system adds a high burden to them. Operational focus is possibly shifted as at first, they strive to earn profit to grow their business, become an effort to how to generate income to be able paying interest and secure their own assets. Unlike the profit-sharing scheme in Sharia principles, the fund provider, in this case the Sharia bank, according to the MUI fatwa is obliged to bear the losses incurred to the customer unless there is a deliberate mistake by the customer such as negligence or violation of the agreement. The elimination of interest, which is replaced by a profit-sharing scheme, becomes a bridge for the capital needs of micro-businesses and minimizes the emergence of new problems due to interest expenses (Nugroho \& Nugraha, 2020). Profit sharing schemes offer a fairer allocation of resources than the interest system as these findings supports (Ellahi, Bukhari \& Naeem 2010) and (Nugroho \& Nugraha 2020).

In addition, there are several alternative Islamic financing schemes that can be taken according to customer needs and abilities. Variations in sharia financing schemes offer wider opportunities for real customer needs (Ellahi, Bukhari \& Naeem, 2010) so as to improve the social and economic balance of microentrepreneurs. In article 19 of Law number 21/2008 concerning Islamic Banking, it is stated that Islamic financing provides an alternative financing model consisting of mudârabah (profit sharing), musyarakah (equity participation), murabahah (buying and selling of goods for a profit), ijârah (pure lease), ijârah wa iqtinâ (lease with the option of transferring ownership of the leased asset), the salam contract, the istithnâ 'contract, the ijârah al-muntahiya bi-altamlîk contract (leasing that ends with ownership). Islamic bank financing products are more 
varied than conventional bank products so that the sharia principles applied in product variations provide wider opportunities to meet customer needs including micro business actors, as found by (Ellahi, Bukhari \& Naeem 2010) and (Ali, Ahmad \& Kamaruddin 2020). The test results in this study also support Elasrag (2016) and Thaker, Kanan \& Sakaran (2019) that the spiritual commitment between fund providers and users of funds has provided sufficient security in Islamic financing transactions. In the sharia financing contract, aspects of honesty, trust and the integration of assets of the two parties guarantee the security of the Sharia financing transaction. However, in terms of applying sharia principles based on products in sharia financing, the banking sector still has to make improvements as there is still found a part of customer dissatisfaction in this study.

Experience in proposing financing by micro-entrepreneurs in this study proves that although they have some limitations, they find it easy to access Sharia financing. According to Yussuf (2017), flexibility in the Sharia financing scheme has a positive impact on the affordability of micro entrepreneurs. The test results prove that the requirements in applying for financing are sufficiently good to be fulfilled by micro entrepreneurs. The simplification of procedures provided in applying for Sharia financing has motivated business actors to utilize financing instruments. In addition, the installments that are determined based on the agreement in the Sharia financing contracts have met the expectations of the customers as most of the customers stated that they had a good experience in fulfilling installments. However, the result shows the difference from what is stated in Nurhasanah, Nurhayati \& Surahman (2020) where access to finance imposes high administrative costs, and Huda (2012) related to high margins in the Sharia financing contract.

Sharia financing schemes that allow micro businesses to take advantage of financing without personal asset guarantees are the right solution for microbusiness development problems. However, some micro business actors apply financing to be able to fulfill their fixed assets and other production equipment. It is very possible that they do not have personal assets beyond their basic life needs to be guaranteed. There is a concern in this collateral problem if they use their principal asset and default occurs, their situation will get worse without any assets. This concern then makes micro entrepreneurs reluctant to apply for financing that requires them to guarantee the only valuable asset they have. Therefore, the presence of Sharia financing through the ijarah and Murabaha contracts is expected to be utilized properly by more micro entrepreneurs in Indonesia.

The availability of clear information is needed by micro-entrepreneurs in determining their financing decisions. The results showed that Islamic banking services in Islamic financing transactions have been supported by information media that can be reached by micro-entrepreneurs with all the limitations they have. Not only through print and digital media, but micro-entrepreneurs also get consulting services with friendly and professional employees. In Sharia principles, clarity of information is very important to avoid fraud in transactions. Sufficient transparency of information supports the commitment of honesty and trust of both parties in the Sharia law. The opinion of respondents in general in 
this study is in line with what was expressed in Nugroho \& Nugraha (2020) that Islamic banking consulting services help micro entrepreneurs to make proper financing decisions and be able to better manage their business and finances. However, the results of the study are not in line with Ali, Bushera \& Yesuf (2020) in relation to the shortage of skilled Islamic banking workers. Based on the experiences of respondents in general, they have been served well by employees who are friendly and have the upper hand with information, or in other words are professionals. More respondents who get a fairly good experience than vice versa. However, some dissatisfaction is still found in financing services by micro entrepreneurs. Sharia banking still needs to continue to improve the capacity and capability of its employees to provide better services and help micro entrepreneurs understand and are more interested in choosing transactions with Sharia principles. Thus, it is argued that the existence of Sharia banking in accordance with its Syariah principles is better in being a solution to the problem of accessibility of micro-business financing and supporting the state in developing micro-businesses in Indonesia.

\section{CONCLUSION}

Micro enterprises, with their various limitations, must face problems in obtaining access to general banking credit. The presence of Islamic banking is expected to be a solution for micro businesses by uniquely applying Sharia principles. This study aims to analyze how the accessibility of micro businesses in Semarang and its surroundings in obtaining Islamic financing. By using a descriptive quantitative approach, this study examined the opinions of 184 respondents including micro business actors who are currently or have previously utilized Sharia financing for their business. The results of the study prove that access to finance for micro entrepreneurs has been helped by the presence of Islamic banking through a variety of products, easy requirements and administration and adequate services. In general, respondents gave positive opinions based on their experience in utilizing Sharia financing. However, some answers with regard to the employees that is very bad were still found from a small proportion of respondents, which means that Islamic banking still has to keep trying to improve its performance in implementing Sharia principles. Thus, the objective in the principles of sharia towards ummah welfare would be achieved.

Limitations in this study occur because the data is only obtained from respondents in one city, so the results of the research cannot be generalized to other areas or wider areas such as all regions in Central Java and Indonesia. In addition, the questionnaire method may be less representative than the interview method to explore respondents' opinions. Another limitation occurs because the data collection methods used by using questionnaires can contain subjectivity and reflect unreal circumstances.

Subsequent research can be expanded by comparing research results from various regions or countries with a more modern business unit background. In addition, the design of the questionnaire for future research can better avoid subjectivity, or it can also be supported by physical documents. The results of this study can be implicated for the development of micro-businesses in Indonesia by introducing alternative financing besides commercial bank credit 
and credit assistance from the government for capital problems, namely Islamic financing products. This research can also be implied to improve the quality of Islamic banking services to improve strategies in achieving social goals in Islamic principles

\section{REFERENSI}

Ali, A. S., Bushera, I. and Yesuf, A. J. (2020) 'The potential of Islamic financial institutions in promoting small and medium enterprises (SMEs) in Ethiopia', Economic Science and Political Economy, 7(3), pp. 188-203. doi: 10.1007/978-1-349-12761-0_27.

Ali, H., Ahmad, I. and Kamaruddin, B. H. (2020) 'Efficiency performance of smes firms: A case study of islamic financing guarantee scheme of credit guarantee corporation', Malaysian Journal of Consumer and Family Economics, 24(S2), pp. 120-134.

Biancone, P. Pietro and Radwan, M. (2015) 'Sharia Compliant "Possibility for Italian SMEs"', European Journal of Islamic Finance, (1), pp. 1-10. doi: 10.13135/2421-2172/908.

Elasrag, H. (2016) Islamic Finance for SMES, SSRN Electronic Journal. doi: 10.2139 /ssrn.2842160.

Ellahi, N., Bukhari, T. A. and Naeem, M. (2010) 'Role Of Islamic Modes Of Financing For Growth Of SMES A Case Study Of Islamabad City', International Journal of Academic Research, 2(6), pp. 161-172.

Hadzic, M. and Pavlovic, P. (2019) 'Rethinking strategy for SMEE support in the light of the entrepreneurial ecosystem', Emerging Science Journal, 3(6), pp. 389-394. doi: 10.28991/esj-2019-01201.

Huda, A. N. (2012) 'The Development of Islamic Financing Scheme for SMEs in a Developing Country: The Indonesian Case', Procedia - Social and Behavioral Sciences. Aulia Nurul Huda, 52, pp. 179-186. doi: 10.1016/j.sbspro.2012.09.454.

Lee, N., Sameen, H. and Cowling, M. (2015) 'Access to finance for innovative SMEs since the financial crisis', Research Policy. Elsevier B.V., 44(2), pp. 370-380. doi: 10.1016/j.respol.2014.09.008.

Margunani, Setiawan, A. B. and Kistant, N. R. (2019) 'Kajian aksesibilitas umkm dan ikm terhadap lembaga keuangan di kota semarang', Jurnal Riptek, 13(2), pp. 147-157.

Nightingale, P. and Coad, A. (2014) 'Muppets and gazelles: political and methodologicalbiases in entrepreneurship research.', Industrial and Corporate Change, 23(1), pp. 113-143.

Nugroho, L. and Nugraha, E. (2020) 'The Role of Islamic Banking and ECommerce for The Development of Micro, Small, and Medium Entrepreneur Businesses', Business, Economics and Management Research Journal, 3(1), pp. 11-24. Available at: https://dergipark.org.tr/en/pub/bemarej/issue/54139/681545.

Nurhasanah, N., Nurhayati, N. and Surahman, M. (2020) 'Micro finance in sharia rural banks in Indonesia: A case study', Entrepreneurship and Sustainability Issues, 7(4), pp. 3455-3463. doi: 10.9770/jesi.2020.7.4(58).

O'Sullivan, M. (2005) 'Finance and Innovation', in Fagerberg, J., Mowery, D., 
Nelson,R. (Eds.). The Oxford Handbook of Innovation. Oxford: Oxford University Press, pp. 240-265.

Prijadi, R. et al. (2020) 'Financing needs of micro-enterprises along their evolution', International Journal of Ethics and Systems, 36(2), pp. 263-284. doi: 10.1108/IJOES-05-2018-0071.

Shaban, M., Duygun, M. and Fry, J. (2016) 'SME's lending and Islamic finance. Is it a "win-win" situation?', Economic Modelling. Elsevier B.V., 55, pp. 1-5. doi: 10.1016/j.econmod.2016.01.029.

Thaker, M. T., Kanan, H. and Sakaran, C. (2019) 'Discussion on Islamic Finance and Small Medium Enterprises' Financial Accessibility', Al-Iqtishad: Jurnal Ilmu Ekonomi Syariah, 11(2), pp. 303-340. doi: 10.15408/aiq.v11i1.7343.

Wardani, B. K. and Pramono, J. (2016) 'Perbankan Syariah: Alternatif Pendanaan Usaha Mikro, Kecil, Menengah (UMKM)', Among Makarti, 9(17), pp. 6078.

Wasiuzzaman, S. et al. (2020) 'Creditworthiness and access to finance of SMEs in Malaysia: do linkages with large firms matter?', Journal of Small Business and Enterprise Development, 27(2), pp. 197-217. doi: 10.1108/JSBED-032019-0075.

Yussuf, A. (2017) Effect of Islamic Banking on Growth of Small Medium Enterprises in Nairobi: A Case Study of First Community Bank. United States International University-Africa. doi: 10.1080/13648470.2015.1126081. 